\title{
Paenibacillus puldeungensis sp. nov., isolated from a grassy sandbank
}

Correspondence
Wonyong Kim
kimwy@cau.ac.kr

\author{
Jitsopin Traiwan, Mi-Hak Park and Wonyong Kim
}

Department of Microbiology and Research Institute for Translational System Biomics, Chung-Ang University College of Medicine, 221 Heukseok-dong, Dongjak-gu, Seoul 156-756, Republic of Korea

\begin{abstract}
The taxonomic position of a Gram-stain-positive, rod-shaped, endospore-forming, facultatively anaerobic bacterial strain, CAU $9324^{\top}$, isolated from a grassy sandbank was investigated by using a polyphasic approach. Strain CAU $9324^{\top}$ grew optimally at $30{ }^{\circ} \mathrm{C}$ and $\mathrm{pH} 6.0$. The cellwall peptidoglycan contained meso-diaminopimelic acid. The major isoprenoid quinone was menaquinone-7 (MK-7). The polar lipid profile consisted of diphosphatidylglycerol as the major component. The predominant cellular fatty acid was anteiso- $\mathrm{C}_{15}: 0$. The DNA G+C content of strain CAU $9324^{\top}$ was 48.8 mol\%. Phylogenetic analyses based on $16 \mathrm{~S}$ rRNA gene sequences revealed that the strain belonged to the genus Paenibacillus, showing $<96.4 \%$ similarity to the type strains of all recognized Paenibacillus species. On the basis of phenotypic, chemotaxonomic and genotypic data, strain CAU $9324^{\top}$ was considered to represent a novel species of the genus Paenibacillus, for which the name Paenibacillus puldeungensis sp. nov. is proposed. The type strain is CAU $9324^{\top}\left(=\right.$ KCTC $13718^{\top}=$ CCUG $\left.59189^{\top}\right)$.
\end{abstract}

The genus Paenibacillus was proposed by Ash et al. (1993, 1994) and is the type genus of the family Paenibacillaceae. Paenibacillus species are widely distributed in the environment and play significant roles in microbial communities (Reva et al., 1995). Generally, members of the genus produce endospores, possess anteiso- $\mathrm{C}_{15: 0}$ as the major cellular fatty acid and have genomic DNA G $+\mathrm{C}$ contents in the range 39-54 mol\% (Shida et al., 1997; Saha et al., 2005). In the course of screening micro-organisms from a sample of grassy sandbank from DaeYiJac Island, Republic of Korea, a facultatively anaerobic, Gram-stain-positive, endospore-forming bacterium (designated strain CAU $9324^{\mathrm{T}}$ ) was isolated and characterized. On the basis of data from the present polyphasic investigation, strain CAU $9324^{\mathrm{T}}$ is considered to represent a novel species of the genus Paenibacillus.

Strain CAU $9324^{\mathrm{T}}$ was isolated on glucose-yeast extract agar (GYEA) (per litre: $10 \mathrm{~g}$ yeast extract, $10 \mathrm{~g}$ glucose, $15 \mathrm{~g}$ agar) supplemented with cycloheximide $\left(50 \mathrm{mg} \mathrm{l}^{-1}\right)$ and nalidixic acid (20 $\mathrm{mg} \mathrm{l}^{-1}$ ) (Gordon \& Mihm, 1962). A sample was diluted with sterilized distilled water. Serial dilutions were spread onto GYEA medium and incubated under aerobic conditions at $30{ }^{\circ} \mathrm{C}$ for 3 days.

Strain CAU $9324^{\mathrm{T}}$ was preserved at $-70{ }^{\circ} \mathrm{C}$ in GYE broth supplemented with $25 \%$ (v/v) glycerol. The morphology of

The GenBank/EMBL/DDBJ accession number for the $16 \mathrm{~S}$ rRNA gene sequence of strain CAU $9324^{\top}$ is GU187433.

Two supplementary figures are available with the online version of this paper. the cells and spores was examined by light microscopy (model DM 1000; Leica). The presence of flagella was examined by scanning electron microscopy (model JSM5410LV; JEOL) by using cells from an exponentially growing culture. Gram staining was carried out by using the procedure described by Doetsch (1981).

Catalase activity was determined by bubble production in a $3 \%(\mathrm{v} / \mathrm{v})$ hydrogen peroxide solution. Oxidase activity was determined based on the oxidation of $1 \%(\mathrm{w} / \mathrm{v})$ tetramethyl- $p$-phenylenediamine (Merck). Acid production from carbohydrates was tested by using the API 50CHB system (bioMérieux). Enzyme activity was determined with the API ZYM system (bioMérieux), and other physiological and biochemical tests were performed with the API 20E system (bioMérieux) according to the manufacturer's instructions. Growth at 20, 30, 37 and $45{ }^{\circ} \mathrm{C}$ was determined on trypticase soy agar (TSA; Difco) in an aerobic incubator (model MIR-253; Sanyo) or anaerobic chamber (model Bactron; Sheldon). The $\mathrm{pH}$ range for growth was tested in trypticase soy broth (TSB) medium at $\mathrm{pH}$ 3.0-11.0. Growth with $0-15 \%(w / v) ~ N a C l$ at $30{ }^{\circ} \mathrm{C}$ was investigated in TSB.

Cellular fatty acid methyl esters were extracted by acid methanolysis (Minnikin et al., 1980) after incubation for 3 days on TSA and were analysed by using an Agilent Technologies model 56890N gas chromatograph (Microbial Identification System Instrument) equipped with a cross-linked $5 \%$ phenyl methyl silicon-fused silica capillary column (HP 19091B-102). Preparation of cell walls from the test strain and analysis of peptidoglycan 
Table 1. Differential phenotypic properties between strain $\mathrm{CAU} 9324^{\top}$ and the type strains of closely related Paenibacillus species

Strains: 1 , CAU $9324^{\mathrm{T}} ; 2$, P. macerans KCTC $1822^{\mathrm{T}} ; 3$, P. timonensis KCTC $3995^{\mathrm{T}}$; 4, P. motobuensis KCTC $3992^{\mathrm{T}}$; 5 , P. sanguinis KCTC $3993^{\mathrm{T}}$. Data were obtained in this study unless indicated. + , Positive; - , negative; $\mathrm{w}$, weakly positive; ND, no data available.

\begin{tabular}{|c|c|c|c|c|c|}
\hline Characteristic & 1 & 2 & 3 & 4 & 5 \\
\hline Catalase & - & + & + & + & + \\
\hline Oxidase & + & + & + & + & - \\
\hline Nitrate reduction & + & + & - & - & - \\
\hline Growth in $5 \% \mathrm{NaCl}$ & + & - & - & $\mathrm{W}$ & + \\
\hline Growth at $50{ }^{\circ} \mathrm{C}$ & - & + & + & + & + \\
\hline \multicolumn{6}{|l|}{ Acid production from: } \\
\hline Glycerol & + & + & - & - & - \\
\hline D-Arabinose & - & + & + & - & + \\
\hline L-Arabinose & + & + & + & - & - \\
\hline Ribose & + & + & + & + & - \\
\hline D-Xylose & + & + & + & + & - \\
\hline Methyl $\beta$-D-xylopyranoside & + & - & + & + & - \\
\hline Galactose & - & - & + & + & - \\
\hline Glucose & + & + & + & - & + \\
\hline Fructose & - & + & + & - & - \\
\hline Mannose & - & + & + & - & - \\
\hline Rhamnose & - & + & - & + & - \\
\hline Mannitol & - & + & - & + & - \\
\hline Sorbitol & - & + & - & - & - \\
\hline Methyl $\alpha$-D-mannopyranoside & - & - & + & - & - \\
\hline Methyl $\alpha$-D-glucoside & - & + & + & - & - \\
\hline$N$-Acetylglucosamine & - & - & + & - & - \\
\hline Amygdalin & - & + & + & - & - \\
\hline Arbutin & - & + & + & - & - \\
\hline Salicin & + & + & + & + & - \\
\hline Maltose & + & + & + & + & - \\
\hline Lactose & + & + & + & + & - \\
\hline Melibiose & + & + & + & + & - \\
\hline Sucrose & + & + & - & - & - \\
\hline Trehalose & - & + & + & + & - \\
\hline Inulin & + & + & - & + & - \\
\hline Melezitose & - & + & - & - & - \\
\hline Raffinose & + & + & + & - & - \\
\hline Glycogen & - & + & + & + & - \\
\hline Gentiobiose & + & - & + & $\mathrm{w}$ & - \\
\hline Turanose & - & + & - & + & - \\
\hline D-Arabitol & - & + & - & - & - \\
\hline Gluconate & + & - & + & - & - \\
\hline 5-Ketogluconate & - & - & - & - & + \\
\hline \multicolumn{6}{|l|}{ Hydrolysis of: } \\
\hline Gelatin & - & - & - & + & + \\
\hline Starch & + & + & + & + & - \\
\hline \multicolumn{6}{|l|}{ Enzyme activity } \\
\hline Esterase & - & + & + & + & - \\
\hline Esterase lipase & - & - & + & + & + \\
\hline Leucine arylamidase & + & $\mathrm{w}$ & + & + & - \\
\hline Valine arylamidase & + & - & + & - & - \\
\hline Cystine arylamidase & + & - & - & - & - \\
\hline Trypsin & + & - & + & + & - \\
\hline
\end{tabular}

Table 1. cont.

\begin{tabular}{|c|c|c|c|c|c|}
\hline Characteristic & 1 & 2 & 3 & 4 & 5 \\
\hline$\alpha$-Chymotrypsin & + & - & + & - & - \\
\hline$\alpha$-Galactosidase & + & + & + & + & - \\
\hline$\beta$-Glucuronidase & + & + & + & + & - \\
\hline$\alpha$-Glucosidase & + & + & + & - & - \\
\hline$\beta$-Glucosidase & + & + & + & + & - \\
\hline$N$-Acetyl- $\beta$-glucosaminidase & - & - & + & + & + \\
\hline DNA G + C content $(\mathrm{mol} \%)$ & 48.8 & $\mathrm{ND}$ & ND & $47^{\star}$ & $\mathrm{ND}$ \\
\hline
\end{tabular}

${ }^{\star}$ Data taken from Iida et al. (2005).

structures were carried out by using the methods described by Schleifer (1985), with the modification that TLC was performed on cellulose sheets instead of paper chromatography. Menaquinones were analysed as described by Komagata \& Suzuki (1987) by using reversed-phase HPLC. Polar lipids were extracted and analysed by twodimensional TLC according to Minnikin et al. (1984).

The genomic DNA of strain CAU $9324^{\mathrm{T}}$ was extracted according to the method of Marmur (1961). The 16S rRNA gene of the strain was amplified by PCR following established procedures (Nam et al., 2004). The amplified $16 \mathrm{~S}$ rRNA gene was sequenced directly by using a BigDye Terminator Cycle Sequencing kit (Applied Biosystems) and an automatic DNA sequencer (model 3730; Applied Biosystems). Multiple alignments with sequences of a wide selection of Paenibacillus species and calculation of sequence similarities were carried out via the EzTaxon server (Chun et al., 2007) and by using the CLUSTAL X program (Thompson et al., 1997). Evolutionary distance matrices were generated by the neighbour-joining method as described by Jukes \& Cantor (1969). Phylogenetic trees were constructed by using the neighbour-joining (Saitou \& Nei, 1987), least-squares (Fitch \& Margoliash, 1967) and maximum-likelihood (Felsenstein, 1981) methods from the PHYLIP suite of programs (Felsenstein, 1989), and tree topology was evaluated by the bootstrap resampling method with 1000 replicates (Felsenstein, 1985) of the neighbour-joining dataset with the SEQBOOT and CONSENSE programs from the PHYLIP package. The $\mathrm{G}+\mathrm{C}$ content of the genomic DNA was determined by HPLC according to the method of Tamaoka \& Komagata (1984) with the modification that DNA was hydrolysed and the resultant nucleotides were analysed by reversed-phase HPLC.

Cells of strain CAU $9324^{\mathrm{T}}$ were Gram-stain-positive, sporeforming, non-motile and facultatively anaerobic. Colonies were white and flat, with a smooth surface and entire margins. Cells were short rods, approximately $0.3 \times 1.3-$ $2.3 \mu \mathrm{m}$, and the endospores were terminal and were formed in swollen sporangia (Supplementary Fig. S1, available in IJSEM Online). Growth was observed on GYEA medium at $20-45{ }^{\circ} \mathrm{C}$, with optimal growth at $30{ }^{\circ} \mathrm{C}$. In TSB, growth occurred at $\mathrm{pH}$ 5.0-11.0, with optimal 
growth at $\mathrm{pH}$ 6.0. Strain CAU $9324^{\mathrm{T}}$ grew in the presence of $0-15 \%(\mathrm{w} / \mathrm{v}) \mathrm{NaCl}$, with optimal growth on medium containing $3 \%(\mathrm{w} / \mathrm{v}) \mathrm{NaCl}$.

The phenotypic properties of strain CAU $9324^{\mathrm{T}}$ are detailed in Table 1. The strain was oxidase-positive but catalase-negative. Acid production occurred from glycerol, $\mathrm{L}$-arabinose, ribose, D-xylose, methyl $\beta$-D-xylopyranoside, glucose, aesculin, salicin, cellobiose, maltose, lactose, melibiose, sucrose, inulin, raffinose, starch, gentiobiose and gluconate, but not from erythritol, D-arabinose, Lxylose, adonitol, galactose, fructose, mannose, sorbose, rhamnose, dulcitol, inositol, mannitol, sorbitol, methyl $\alpha-$ D-mannopyranoside, methyl $\alpha$-D-glucoside, $N$-acetylglucosamine, amygdalin, arbutin, trehalose, melezitose, glycogen, xylitol, turanose, D-lyxose, D-tagatose, D- or Lfucose, D- or L-arabitol, 2-ketogluconate or 5-ketogluconate. Activities were detected for leucine arylamidase, valine arylamidase, cystine arylamidase, trypsin, $\alpha$-chymotrypsin, $\alpha$-galactosidase, $\beta$-glucuronidase, $\alpha$-glucosidase and $\beta$-glucosidase, but not alkaline phosphatase, esterase, esterase lipase, lipase, acid phosphatase, naphthol-AS-BIphosphohydrolase, $\beta$-glucosidase, $N$-acetyl- $\beta$-glucosaminidase, $\alpha$-mannosidase or $\alpha$-fucosidase.

Strain CAU $9324^{\mathrm{T}}$ contained meso-diaminopimelic acid in the cell-wall peptidoglycan, and whole-cell hydrolysates contained mainly ribose. The predominant isoprenoid quinone was unsaturated menaquinone-7 (MK-7). Strain CAU $9324^{\mathrm{T}}$ displayed a polar lipid pattern that consisted of diphosphatidylglycerol, phosphatidylglycerol, phosphatidylethanolamine and two unknown aminophospholipids (Supplementary Fig. S2). The cellular fatty acid profile of strain CAU $9324^{\mathrm{T}}$ grown on TSA was characterized as containing saturated branched and straight-chain components such as iso- $\mathrm{C}_{14: 0}(5.2 \%), \mathrm{C}_{14: 0}(3.0 \%)$, iso- $\mathrm{C}_{15: 0}$

Table 2. Cellular fatty acid compositions of strain CAU $9324^{\top}$ and the type strains of closely related Paenibacillus species

Strains: 1 , CAU $9324^{\mathrm{T}} ; 2$, P. macerans KCTC $1822^{\mathrm{T}}$; 3, P. timonensis KCTC $3995^{\mathrm{T}}$; 4, P. motobuensis KCTC $3992^{\mathrm{T}}$; 5, P. sanguinis KCTC $399^{\mathrm{T}}$. Data were obtained in this study and are percentages of total fatty acids. -, Not detected.

\begin{tabular}{|c|c|c|c|c|c|}
\hline Fatty acid & 1 & 2 & 3 & 4 & 5 \\
\hline \multicolumn{6}{|l|}{ Straight-chain } \\
\hline $\mathrm{C}_{14: 0}$ & 3.0 & 2.4 & 3.5 & 1.8 & 1.4 \\
\hline $\mathrm{C}_{15: 0}$ & 1.5 & 2.4 & 2.0 & 1.7 & 8.4 \\
\hline $\mathrm{C}_{16: 0}$ & 17.0 & 8.3 & 10.7 & 8.0 & 15.3 \\
\hline \multicolumn{6}{|c|}{ Branched-chain } \\
\hline anteiso- $C_{15: 0}$ & 53.2 & 32.7 & 43.6 & 40.7 & 48.3 \\
\hline anteiso- $C_{17: 0}$ & 3.9 & 12.8 & 4.4 & 8.2 & 3.5 \\
\hline iso- $\mathrm{C}_{14: 0}$ & 5.2 & 3.4 & 7.2 & 2.7 & 2.9 \\
\hline iso- $\mathrm{C}_{15: 0}$ & 3.9 & 9.2 & 11.4 & 15.0 & 3.5 \\
\hline iso- $\mathrm{C}_{16: 0}$ & 9.0 & 21.8 & 13.7 & 13.3 & 11.0 \\
\hline iso- $\mathrm{C}_{17: 0}$ & - & 7.1 & 2.4 & 8.8 & 1.8 \\
\hline
\end{tabular}

(3.9\%), anteiso- $\mathrm{C}_{15: 0}(53.2 \%), \mathrm{C}_{15: 0}(1.5 \%)$, iso- $\mathrm{C}_{16: 0}$ $(9.0 \%), \mathrm{C}_{16: 0}(17.0 \%)$ and anteiso- $\mathrm{C}_{17: 0}(3.9 \%)$ (Table 2$)$.

The almost-complete 16S rRNA gene sequence (1409 bp) of strain CAU $9324^{\mathrm{T}}$ was determined and compared with the corresponding sequences of other bacterial strains in the GenBank database. Phylogenetic analyses indicated that the strain belonged to the genus Paenibacillus, with levels of $16 \mathrm{~S}$ rRNA gene sequence similarity to all recognized Paenibacillus species ranging from 95.2 to $96.4 \%$. The phylogenetic tree obtained with the neighbour-joining method is shown in Fig. 1. Strain CAU $9324^{\mathrm{T}}$ was related most closely to Paenibacillus motobuensis $\mathrm{MC}^{\mathrm{T}}{ }^{\mathrm{T}}(96.4 \%$ 16S rRNA gene sequence similarity), P. macerans IAM $12467^{\mathrm{T}}(96.2 \%)$, P. sanguinis $2301083^{\mathrm{T}}(96.2 \%)$, P. timonensis $2301032^{\mathrm{T}}(96.2 \%)$ and $P$. barengoltzii SAFN- $016^{\mathrm{T}}(96.2 \%)$. The DNA G + C content of strain CAU $9324^{\mathrm{T}}$ was $48.8 \mathrm{~mol} \%$.

Therefore, on the basis of the data presented, strain CAU $9324^{\mathrm{T}}$ is considered to represent a novel species of the genus Paenibacillus, for which the name Paenibacillus puldeungensis sp. nov. is proposed.

\section{Description of Paenibacillus puldeungensis sp. nov.}

Paenibacillus puldeungensis (pul.deun.gen'sis. N.L. masc. adj. puldeungensis of/from puldeung, the Korean word for a

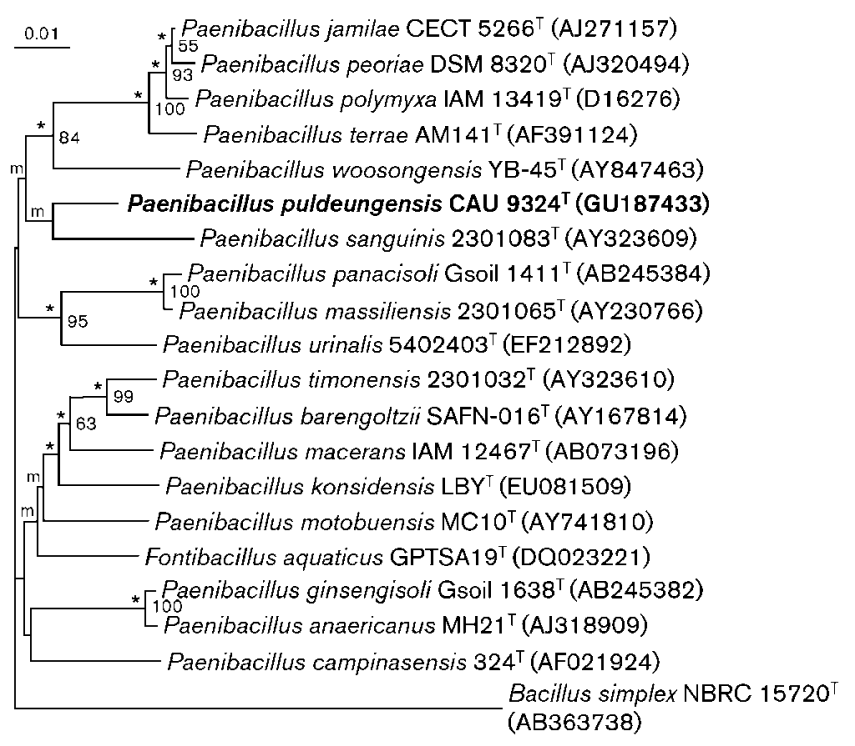

Fig. 1. Neighbour-joining phylogenetic tree based on nearly complete 16S rRNA gene sequences showing the relationship between strain CAU $9324^{\top}$ and the type strains of closely related members of the genus Paenibacillus. Branches of the tree that were also found by using the least-squares and/or maximumlikelihood treeing algorithms are indicated by asterisks (both algorithms) or by ' $m$ ' (maximum-likelihood only). Numbers at nodes indicate levels of bootstrap support based on a neighbour-joining analysis of 1000 resampled datasets; only values $>50 \%$ are given. Bar, 0.01 substitutions per nucleotide position. 
grassy sandbank such as the one from which the type strain was isolated).

Cells are Gram-stain-positive, facultatively anaerobic, non-motile, spore-forming rods $(0.3-0.4 \times 0.9-1.2 \mu \mathrm{m})$. Endospores are terminal and form within swollen sporangia. Colonies are white and flat with a smooth surface and have entire margins on GYEA medium after incubation at $30{ }^{\circ} \mathrm{C}$ for $72 \mathrm{~h}$. Growth occurs at $20-45{ }^{\circ} \mathrm{C}$ (optimum $30{ }^{\circ} \mathrm{C}$ ), at $\mathrm{pH}$ 5.0-11.0 (optimum $\mathrm{pH}$ 6.0) and in the presence of 0 $15 \%(\mathrm{w} / \mathrm{v}) \mathrm{NaCl}$ (optimum 3\%) (concentrations above $15 \% \mathrm{NaCl}$ not tested). Positive for oxidase and nitrate reduction. Positive for activities of leucine arylamidase, valine arylamidase, cystine arylamidase, trypsin, $\alpha$-chymotrypsin, $\alpha$-galactosidase, $\beta$-glucuronidase, $\alpha$-glucosidase and $\beta$-glucosidase. Produces acid from glycerol, L-arabinose, ribose, D-xylose, methyl $\beta$-D-xylopyranoside, glucose, aesculin, salicin, cellobiose, maltose, lactose, melibiose, sucrose, inulin, raffinose, starch, gentiobiose and gluconate. The diagnostic amino acid in cell-wall hydrolysates is mesodiaminopimelic acid. Whole-cell hydrolysates contain mainly ribose. The major isoprenoid quinone is MK-7. The major polar lipid is diphosphatidylglycerol. The predominant cellular fatty acids are iso- $\mathrm{C}_{14: 0}, \mathrm{C}_{14: 0}$, iso- $\mathrm{C}_{15: 0}$, anteiso- $\mathrm{C}_{15: 0}, \mathrm{C}_{15: 0}$, iso- $\mathrm{C}_{16: 0}, \mathrm{C}_{16: 0}$ and anteiso- $\mathrm{C}_{17: 0}$. The $\mathrm{DNA} \mathrm{G}+\mathrm{C}$ content of the type strain is $48.8 \mathrm{~mol} \%$.

The type strain, CAU $9324^{\mathrm{T}}$ (=KCTC $13718^{\mathrm{T}}=\mathrm{CCUG}$ $59189^{\mathrm{T}}$ ), was isolated from a sample taken from a grassy sandbank on DaeYiJac Island in the Republic of Korea.

\section{Acknowledgements}

This work was supported by the 21C Frontier Microbial Genomics and Applications Center Program, Ministry of Education, Science \& Technology (grant 11-2008-03-002-00), Republic of Korea.

\section{References}

Ash, C., Priest, F. G. \& Collins, M. D. (1993). Molecular identification of rRNA group 3 bacilli (Ash, Farrow, Wallbanks and Collins) using a PCR probe test. Proposal for the creation of a new genus Paenibacillus. Antonie van Leeuwenhoek 64, 253-260.

Ash, C., Priest, F. G. \& Collins, M. D. (1994). Paenibacillus gen. nov. In Validation of the Publication of New Names and New Combinations Previously Effectively Published Outside the IJSB, List no. 51. Int J Syst Bacteriol 44, 852.

Chun, J., Lee, J. H., Jung, Y., Kim, M., Kim, S., Kim, B. K. \& Lim, Y. W. (2007). EzTaxon: a web-based tool for the identification of prokaryotes based on $16 \mathrm{~S}$ ribosomal RNA gene sequences. Int J Syst Evol Microbiol 57, 2259-2261.

Doetsch, R. N. (1981). Determinative methods of light microscopy. In Manual of Methods for General Bacteriology, pp. 21-33. Edited by P. Gerhardt, R. G. E. Murray, R. N. Costilow, E. W. Nester, W. A. Wood, N. R. Krieg \& G. H. Phillips. Washington, DC: American Society for Microbiology.
Felsenstein, J. (1981). Evolutionary trees from DNA sequences: a maximum likelihood approach. J Mol Evol 17, 368-376.

Felsenstein, J. (1985). Confidence limits on phylogenies: an approach using the bootstrap. Evolution 39, 783-791.

Felsenstein, J. (1989). PHYLIP - phylogeny inference package (version 3.2). Cladistics 5, 164-166.

Fitch, W. M. \& Margoliash, E. (1967). Construction of phylogenetic trees. Science 155, 279-284.

Gordon, R. E. \& Mihm, J. M. (1962). Identification of Nocardia caviae (Erikson) nov. comb. Ann N Y Acad Sci 98, 628-636.

lida, K., Ueda, Y., Kawamura, Y., Ezaki, T., Takade, A., Yoshida, S. \& Amako, K. (2005). Paenibacillus motobuensis sp. nov., isolated from a composting machine utilizing soil from Motobu-town, Okinawa, Japan. Int J Syst Evol Microbiol 55, 1811-1816.

Jukes, T. H. \& Cantor, C. R. (1969). Evolution of protein molecules. In Mammalian Protein Metabolism, vol. 3, pp. 21-132. Edited by H. N. Munro. New York: Academic Press.

Komagata, K. \& Suzuki, K. (1987). Lipid and cell-wall analysis in bacterial systematics. Methods Microbiol 19, 161-207.

Marmur, J. (1961). A procedure for the isolation of deoxyribonucleic acid from microorganisms. J Mol Biol 3, 208-218.

Minnikin, D. E., Hutchinson, I. G., Caldicott, A. B. \& Goodfellow, M. (1980). Thin-layer chromatography of methanolysates of mycolic acid-containing bacteria. J Chromatogr A 188, 221-233.

Minnikin, D. E., O’Donnell, A. G., Goodfellow, M., Alderson, G., Athalye, M., Schaal, K. P. \& Parlett, J. H. (1984). An integrated procedure for the extraction of bacterial isoprenoid quinones and polar lipids. J Microbiol Methods 2, 233-241.

Nam, S. W., Kim, W., Chun, J. \& Goodfellow, M. (2004). Tsukamurella pseudospumae sp. nov., a novel actinomycete isolated from activated sludge foam. Int J Syst Evol Microbiol 54, 1209-1212.

Reva, O. N., Vyunitskaya, V. A., Reznik, S. R., Kozachko, I. A. \& Smirnov, V. V. (1995). Antibiotic susceptibility as a taxonomic characteristic of the genus Bacillus. Int J Syst Bacteriol 45, 409-411.

Saha, P., Mondal, A. K., Mayilraj, S., Krishnamurthi, S., Bhattacharya, A. \& Chakrabarti, T. (2005). Paenibacillus assamensis sp. nov., a novel bacterium isolated from a warm spring in Assam, India. Int J Syst Evol Microbiol 55, 2577-2581.

Saitou, N. \& Nei, M. (1987). The neighbor-joining method: a new method for reconstructing phylogenetic trees. Mol Biol Evol 4, 406425.

Schleifer, K. H. (1985). Analysis of the chemical composition and primary structure of murein. Methods Microbiol 18, 123-156.

Shida, O., Takagi, H., Kadowaki, K., Nakamura, L. K. \& Komagata, K. (1997). Transfer of Bacillus alginolyticus, Bacillus chondroitinus, Bacillus curdlanolyticus, Bacillus glucanolyticus, Bacillus kobensis, and Bacillus thiaminolyticus to the genus Paenibacillus and emended description of the genus Paenibacillus. Int J Syst Bacteriol 47, 289298.

Tamaoka, J. \& Komagata, K. (1984). Determination of DNA base composition by reverse-phase high-performance liquid chromatography. FEMS Microbiol Lett 25, 125-128.

Thompson, J. D., Gibson, T. J., Plewniak, F., Jeanmougin, F. \& Higgins, D. G. (1997). The CLUSTAL_X windows interface: flexible strategies for multiple sequence alignment aided by quality analysis tools. Nucleic Acids Res 25, 4876-4882. 